\title{
Omega-3 polyunsaturated fatty acids enrichment alters performance and immune response in infectious bursal disease challenged broilers
}

\author{
Elham Maroufyan ${ }^{1}$, Azhar Kasim", Mahdi Ebrahimi², Tech Chwen Loh', Mohd Hair Bejo ${ }^{3}$, Hailemariam Zerihun ${ }^{3}$, \\ Fatemeh Hosseni ${ }^{4}$, Yong Meng Goh ${ }^{2}$ and Abdoreza Soleimani Farjam²
}

\begin{abstract}
Background: Infectious bursal disease (IBD) results in economic loss due to mortality, reduction in production efficiency and increasing the usage of antibiotics. This study was carried out to investigate the modulatory roles of dietary $n-3$ polyunsaturated fatty acids (PUFA) enrichment in immune response and performance of IBD challenged broiler chickens.

Methods: A total of 300 day old male broiler chicks were assigned to four dietary $n-3$ PUFA ascending levels as the treatment groups (T1: 0.5; T2: 8.0; T3: 11.5; T4: 16.5) using combinations of tuna oil and sunflower oil. All diets were isocaloric and isonitrogenous. On day 28, all birds were challenged with IBD virus. Antibody titer, cytokine production, bursa lesion pre and post-challenge and lymphoid organ weight were recorded.

Results: On d 42 the highest body weight was observed in the T2 and T3 and the lowest in T4 chickens. Feed conversion ratio of the T2 broilers was significantly better than the other groups. Although productive parameters were not responded to the dietary n-3 PUFA in a dose-dependent manner, spleen weight, IBD and Newcastle disease antibody titers and IL-2 and IFN- $\gamma$ concentrations were constantly elevated by n-3 PUFA enrichment.

Conclusions: Dietary n-3 PUFA enrichment may improve the immune response and IBD resistance, but the optimum performance does not coincide with the optimum immune response. It seems that dietary n-3 PUFA modulates the broiler chicken performance and immune response in a dose-dependent manner. Thus, a moderate level of dietary n-3 PUFA enrichment may help to put together the efficiency of performance and relative immune response enhancement in broiler chickens.
\end{abstract}

Keywords: $n-3$ PUFA, immune response, IBD, broiler

\section{Background}

There has been fast growth in the global interest to the effects of diet on various aspects of immune function. Typically, different research groups have assessed different nutrients, each using different animal models. Most of these models focus on selected aspects of immune function without assessing the other functions. It is therefore always difficult to understand the broader modulating influence for instance on the productive parameters. In modern poultry industry, however, within

\footnotetext{
* Correspondence: azhar@agri.upm.edu.my

'Department of Animal Science, Universiti Putra Malaysia,43400 UPM Serdang, Selangor, Malaysia

Full list of author information is available at the end of the article
}

commonly used feed there is an oversupply of $n-6$ polyunsaturated fatty acids (PUFA) and an undersupply of $n$ 3 PUFA, causing an imbalance in the corn-soybean diet. Consumption of $n-3$ PUFA, resulted in incorporation of these fatty acids into lipid membrane of all tissues, including cells of the immune system $[1,2]$. Long chain $n-3$ PUFA showed to improve the immune response and reduce inflammation in different species such as chicken, mice and fish [3-5].

On the other hand, infectious bursal disease (IBD) is one of the most important chicken diseases that have emerged in the last 30 years. IBD viral infection suppresses the immune system in young chickens, making birds sensitive to other diseases [6-8]. In poultry production, it is very 
important to improve immunity for prevention of infectious diseases. Minimizing immunosuppression and its impact is an important factor for success in the broiler production. In vivo and in vitro studies have shown that the target cell in IBD is IgM-bearing B lymphocyte. The acute lytic phase of the virus is associated with a reduction in circulating $\operatorname{IgM}^{+}$cells [8-11]. Immunoglobulin $\mathrm{M}$ is the major class of antibody found in serum, in the primary immune response (first encounter of antigen). Supplementation of dietary n-3 PUFA has shown to increase IgM level, suggesting an immuno-stimulating property of $n-3$ PUFA. immunoglobulins production by $\beta$ cells and interferon- $\gamma($ IFN- $\gamma$ ) is facilitated by interlukin-2 (IL-2). This elevation is more pronounced in docosahexaenoic acid (DHA) rich diet than eicosapentaenoic acid (EPA) rich diet [12]. Another study showed that IgG and IgE response increased to ovalbumin in rats fed a high fish oil diet [13]. It has also demonstrated that $n-3$ PUFA from fish oil have an antiviral effect in mice $[14,15]$. The $n-3$ PUFA in fish oil can affect immune cell activation in both the innate and specific immune systems in different species [4,16-18]. Therefore, diet enrichment with n-3 PUFA consider as an alternative to enhance immune response and disease resistance. Among common sources of fish oil used in biomedical research, tuna oil has an interesting balance of n-3 PUFA and it contains much more DHA than EPA $[19,20]$.

As for the chicken nutrition and immune response, to date, there is no report on immunomodulatory effects of dietary n-3 PUFA under IBD challenge in broiler chickens. Therefore, this study aimed to investigate the influence of dietary n-3 PUFA enrichment on immune response and performance of IBD challenged broiler chickens.

\section{Results}

\section{Nutrient Composition and Fatty Acids Analysis}

Nutrient composition is shown in Table 1 and fatty acid profile of the experimental diets and oils are shown in Table 2 and 3. Linoleic acid $(C 18: 2 n-6)$ was the main $n-6$ PUFA in the diets and it was decreased as the fish oil increased. An opposite trend was observed for EPA and DHA contents while $\alpha$-linolenic acid (C18:3n-3) remained unchanged. The resulting DHA content of the diets were $0,5.6,8.17$ and 11.93 for $\mathrm{T} 1$ to $\mathrm{T} 4$, respectively. Influence of treatment diets on plasma fatty acid composition on d 28 and 42 are shown in Table 4 and 5. It was clearly indicated that the incorporation of fish oil into diet significantly increased the $n-3$ PUFA in plasma. On d 28 and 42 the highest plasma $n-3$ PUFA was observed in the T4 birds diet while the highest plasma $n$ 6 PUFA was measured in T2 birds. The same results were observed in breast muscle on d 42 (Table 6).

\section{Performance Parameters}

There were no effects of dietary n-3 PUFA enrichment on Body weight, feed intake and FCR on d 21 (Table 7).

Table 1 Nutrient composition of experimental diets (\%).

\begin{tabular}{|c|c|c|c|c|c|c|c|c|}
\hline \multirow[b]{2}{*}{ Ingredients } & \multicolumn{4}{|c|}{ 1-21 days } & \multicolumn{4}{|c|}{$22-42$ days } \\
\hline & $\mathrm{T}^{\dagger}$ & T2 & T3 & T4 & T1 & T2 & T3 & T4 \\
\hline Corn & 44.91 & 45.61 & 45.75 & 45.86 & 49.90 & 51.45 & 51.49 & 51.54 \\
\hline Soybean meal & 43.85 & 43.73 & 43.59 & 43.48 & 38.67 & 38.43 & 38.39 & 38.34 \\
\hline Palm oil & 6.58 & 0.00 & 0.00 & 0.00 & 7.31 & 0.00 & 0.00 & 0.00 \\
\hline Sunflower oil & 0.00 & 3.50 & 2.00 & 0.50 & 0.00 & 3.50 & 2.00 & 0.50 \\
\hline Tuna oil & 0.00 & 2.50 & 4.00 & 5.50 & 0.00 & 2.50 & 4.00 & 5.50 \\
\hline Di calcium phosphate & 1.91 & 1.91 & 1.91 & 1.91 & 1.77 & 1.77 & 1.77 & 1.77 \\
\hline Limestone & 1.20 & 1.20 & 1.20 & 1.20 & 1.06 & 1.06 & 1.06 & 1.06 \\
\hline Salt & 0.44 & 0.44 & 0.44 & 0.44 & 0.31 & 0.31 & 0.31 & 0.31 \\
\hline Vitamin premix & 0.30 & 0.30 & 0.30 & 0.30 & 0.30 & 0.30 & 0.30 & 0.30 \\
\hline Mineral premix & 0.30 & 0.30 & 0.30 & 0.30 & 0.30 & 0.30 & 0.30 & 0.30 \\
\hline DL-Methionine & 0.25 & 0.25 & 0.25 & 0.25 & 0.23 & 0.23 & 0.23 & 0.23 \\
\hline Lysine & 0.26 & 0.26 & 0.26 & 0.26 & 0.15 & 0.15 & 0.15 & 0.15 \\
\hline \multicolumn{9}{|c|}{ Calculated composition (\%) } \\
\hline Crude protein & 22.00 & 22.00 & 22.00 & 22.00 & 20.50 & 20.50 & 20.50 & 20.50 \\
\hline ME (Kcal/kg) & 3080 & 3080 & 3080 & 3080 & 3150 & 3150 & 3150 & 3150 \\
\hline Available phosphorus & 0.45 & 0.45 & 0.45 & 0.45 & 0.42 & 0.42 & 0.42 & 0.42 \\
\hline Calcium & 1.00 & 1.00 & 1.00 & 1.00 & 0.90 & 0.90 & 0.90 & 0.90 \\
\hline Methionine & 0.55 & 0.55 & 0.55 & 0.55 & 0.50 & 0.50 & 0.50 & 0.50 \\
\hline Lysine & 1.20 & 1.20 & 1.20 & 1.20 & 1.00 & 1.00 & 1.00 & 1.00 \\
\hline $\mathrm{Na}$ & 0.20 & 0.20 & 0.20 & 0.20 & 0.15 & 0.15 & 0.15 & 0.15 \\
\hline
\end{tabular}

${ }^{\dagger}$ Dietary n-3 PUFA level of 0.5 (T1), 8.0 (T2), 11.5 (T3), 16.5\% (T4). 
Table 2 Fatty acid composition of dietary treatments (percentage of total fatty acids).

\begin{tabular}{|c|c|c|c|c|}
\hline \multirow[b]{2}{*}{ Fatty acids } & \multicolumn{4}{|c|}{ Treatments } \\
\hline & $\mathrm{T}^{\dagger}{ }^{\dagger}$ & $\mathrm{T} 2$ & T3 & T4 \\
\hline 14:0 & 0.8 & 0.9 & 1.8 & 2.5 \\
\hline 15:0 & - & - & - & 0.7 \\
\hline 15:1 & - & - & - & - \\
\hline $16: 0$ & 32.7 & 15.7 & 17.3 & 19.5 \\
\hline 16:1 & - & 1.4 & 2.4 & 3.3 \\
\hline $17: 0$ & - & 0.9 & 1.0 & 1.4 \\
\hline $17: 1$ & - & - & 0.6 & 0.8 \\
\hline 18:0 & 4.1 & 4.9 & 4.9 & 5.6 \\
\hline 18:1 & 39.2 & 27.8 & 26.9 & 23.3 \\
\hline $18: 2 n-6$ & 21.9 & 38.8 & 31.9 & 24.8 \\
\hline $18: 3 n-3$ & - & 0.5 & 0.6 & 0.6 \\
\hline $20: 4 n-6$ & - & 0.6 & 0.7 & 1.1 \\
\hline $20: 5 n-3$ & - & 1.5 & 2.3 & 3.2 \\
\hline $22: 5 n-3$ & - & - & 0.6 & 0.8 \\
\hline $22: 6 n-3$ & - & 5.6 & 8.2 & 11.9 \\
\hline SFA & 38.2 & 23.2 & 25.9 & 30.0 \\
\hline UFA & 61.8 & 76.8 & 74.1 & 69.9 \\
\hline MUFA & 39.5 & 29.5 & 29.9 & 27.5 \\
\hline PUFA $n-3$ & 0.5 & 8.0 & 11.5 & 16.5 \\
\hline PUFA $n-6$ & 21.9 & 39.4 & 32.6 & 25.9 \\
\hline UFA: SFA & 1.6 & 3.5 & 2.9 & 2.3 \\
\hline PUFA: SFA & 0.6 & 2.1 & 1.7 & 1.4 \\
\hline$n-6: n-3$ & 51.7 & 5.1 & 2.8 & 1.6 \\
\hline
\end{tabular}

${ }^{\dagger}$ Dietary $n-3$ PUFA level of 0.5 (T1), 8.0 (T2), 11.5 (T3), 16.5\% (T4).

However, on $\mathrm{d} 42$, birds in $\mathrm{T} 4$ group that received the highest $\mathrm{n}-3$ PUFA showed the lowest body weight $(\mathrm{P}<$ 0.05). A superior FCR was recorded for the birds of group T2. Feed intake was not affected by the dietary $\mathrm{n}-3$ PUFA enrichment throughout the study $(\mathrm{P}>0.05)$.

\section{Lymphoid Organ Weight}

Bursa of Fabricius weight was not influenced by n-3 PUFA enrichment $(P>0.05)$ (Table 8). Spleen weight $7 \mathrm{~d}$ after challenge was increased steadily by dietary treatment from $\mathrm{T} 1$ to $\mathrm{T} 4$ where the lowest was recorded

Table 3 Fatty acid composition of dietary treatments (\%).

\begin{tabular}{llll}
\hline Fatty acids & Palm oil & Tuna oil & Sunflower oil \\
\hline $14: 0$ & 1 & 3.1 & nd \\
$16: 0$ & 45 & 22.8 & 7 \\
$18: 0$ & 4 & 6.7 & 5 \\
$18: 1 n-9$ & 40 & 17.7 & 19 \\
$18: 2 n-6$ & 10 & 1.6 & 68 \\
$18: 3 n-3$ & - & 2.3 & 1 \\
$20: 5 n-3$ & - & 4.6 & - \\
$22: 6 n-3$ & - & 18.3 & - \\
$\mathrm{PV}^{+}(\mathrm{mEq} / \mathrm{Kg})$ & 0.9 & 1.4 & 1.1 \\
\hline
\end{tabular}

${ }^{\dagger} \mathrm{PV}=$ Peroxide value. $\mathrm{nd}=$ not detected.
Table 4 Influence of dietary treatments on plasma fatty acid composition at $\mathbf{2 8}$ days of age in broiler chickens (\%).

\begin{tabular}{|c|c|c|c|c|}
\hline \multirow[b]{2}{*}{ Fatty acids } & \multicolumn{4}{|c|}{ Treatments } \\
\hline & $\mathrm{T}^{\dagger}{ }^{\dagger}$ & $\mathrm{T} 2$ & T3 & $\mathrm{T} 4$ \\
\hline 14:0 & $0.46 \pm 0.03^{b}$ & $0.49 \pm 0.01^{b}$ & $0.67 \pm 0.1^{a}$ & $0.84 \pm 0.1^{a}$ \\
\hline 15:0 & $1.17 \pm 0.2$ & $1.37 \pm 0.1$ & $1.01 \pm 0.2$ & $1.23 \pm 0.2$ \\
\hline $16: 0$ & $21.41 \pm 0.5^{b}$ & $20.84 \pm 0.8^{b}$ & $22.37 \pm 0.6^{a b}$ & $23.99 \pm 0.4^{\mathrm{a}}$ \\
\hline $16: 1$ & $1.66 \pm 0.7$ & $0.61 \pm 0.1$ & $1.02 \pm 0.1$ & $1.14 \pm 0.1$ \\
\hline 17:0 & $0.82 \pm 0.2$ & $0.95 \pm 0.2$ & $0.97 \pm 0.2$ & $0.84 \pm 0.1$ \\
\hline 18:0 & $12.78 \pm 0.2$ & $14.09 \pm 0.5$ & $12.71 \pm 0.3$ & $13.10 \pm 0.6$ \\
\hline $18: 1 n-9$ & $29.15 \pm 1.5^{\mathrm{a}}$ & $15.36 \pm 1.3^{b}$ & $15.53 \pm 0.7^{b}$ & $14.67 \pm 0.9^{b}$ \\
\hline $18: 2 n-6$ & $24.70 \pm 0.7^{b}$ & $30.06 \pm 0.9^{a}$ & $26.41 \pm 1.3^{\mathrm{a}}$ & $21.19 \pm 1.2^{c}$ \\
\hline $18: 3 n-3$ & $0.64 \pm 0.04$ & $0.48 \pm 0.03$ & $0.65 \pm 0.1$ & $0.69 \pm 0.1$ \\
\hline $20: 4 n-6$ & $4.12 \pm 0.9^{\mathrm{ab}}$ & $4.61 \pm 0.5^{\mathrm{a}}$ & $3.57 \pm 0.3^{\mathrm{ab}}$ & $2.95 \pm 0.3^{b}$ \\
\hline $20: 5 n-3$ & - & $1.71 \pm 0.1^{c}$ & $3.21 \pm 0.2^{b}$ & $3.95 \pm 0.2^{\mathrm{a}}$ \\
\hline $22: 6 n-3$ & - & $6.92 \pm 0.1^{c}$ & $9.33 \pm 0.4^{b}$ & $12.52 \pm 0.6^{a}$ \\
\hline SFA & $38.68 \pm 0.7^{b}$ & $39.26 \pm 0.5^{\mathrm{ab}}$ & $39.10 \pm 0.7^{b}$ & $41.69 \pm 0.5^{a}$ \\
\hline UFA & $61.32 \pm 0.7^{a}$ & $60.74 \pm 0.5^{\mathrm{a}}$ & $60.90 \pm 0.7^{\mathrm{a}}$ & $58.31 \pm 0.5^{b}$ \\
\hline MUFA & $31.86 \pm 2.2^{\mathrm{a}}$ & $16.95 \pm 1.3^{b}$ & $17.72 \pm 0.8^{b}$ & $17.01 \pm 1.0^{b}$ \\
\hline PUFA $n-3$ & $0.64 \pm 0.04^{d}$ & $9.12 \pm 0.2^{c}$ & $13.20 \pm 0.5^{b}$ & $17.16 \pm 0.8^{a}$ \\
\hline PUFA $n-6$ & $28.82 \pm 1.6^{b}$ & $34.67 \pm 1.4^{\mathrm{a}}$ & $29.98 \pm 1.2^{b}$ & $24.14 \pm 1.3^{b}$ \\
\hline UFA: SFA & $1.59 \pm 0.1$ & $1.55 \pm 0.03$ & $1.56 \pm 0.05$ & $1.40 \pm 0.03$ \\
\hline PUFA: SFA & $0.76 \pm 0.03^{b}$ & $1.12 \pm 0.1^{a}$ & $1.11 \pm 0.04^{a}$ & $0.99 \pm 0.04^{a}$ \\
\hline$n-6: n-3$ & $45.26 \pm 1.9^{a}$ & $3.80 \pm 0.1^{b}$ & $2.29 \pm 0.2^{c}$ & $1.43 \pm 0.1^{d}$ \\
\hline
\end{tabular}

${ }^{\dagger}$ Dietary $n-3$ PUFA level of 0.5 (T1), 8.0 (T2), 11.5 (T3), 16.5\% (T4). $n=8$ birds/ treatment.

a-d Means with different superscripts within a row differ significantly $(P<$ 0.05).

in T1 and the highest in T4. There were no significant differences in spleen weight pre-challenge or 14 days after challenge.

\section{Histopathological Lesion Score}

The Effect of dietary $n-3$ PUFA enrichment on lesion score of bursa in IBD challenged broiler chickens is presented in Table 9. Dietary treatment was not affected the bursa of Fabricius tissue pathologically throughout the study as measured by lesion scoring $(\mathrm{P}>0.05)$.

\section{Serology}

The effect of dietary $n-3$ PUFA enrichment on serum antibody titer $\left(\log _{10}\right)$ in broilers vaccinated against ND and challenged with IBD virus is shown in Figure 1. Serum IBD and ND antibody titers were not influenced by treatments pre-challenge on $\mathrm{d} 28$ and 14 days after challenge. However, there was a significant alteration in both antibody titers seven days after IBD challenge. Interestingly, this alteration was along with the ascending trend of n-3 PUFA enrichment. The lowest and highest IBD and ND antibody titers were in T1 and T4 chickens, respectively. 
Table 5 Influence of dietary treatments on plasma fatty acid composition at $\mathbf{4 2}$ days of age in broiler chickens (\%).

\begin{tabular}{|c|c|c|c|c|}
\hline \multirow[b]{2}{*}{ Fatty acids } & \multicolumn{4}{|c|}{ Treatments } \\
\hline & $\mathrm{T}^{\dagger}{ }^{\dagger}$ & $\mathrm{T} 2$ & T3 & T4 \\
\hline 14:0 & $0.48 \pm 0.1^{b}$ & $0.61 \pm 0.04^{\mathrm{ab}}$ & $0.77 \pm 0.1^{a}$ & $0.89 \pm 0.1^{a}$ \\
\hline 15:0 & $0.83 \pm 0.1^{b}$ & $0.62 \pm 0.2^{b}$ & $0.84 \pm 0.2^{b}$ & $1.50 \pm 0.1^{\mathrm{a}}$ \\
\hline $16: 0$ & $21.71 \pm 0.7^{b}$ & $23.80 \pm 0.4^{\mathrm{ab}}$ & $24.94 \pm 1.0^{\mathrm{a}}$ & $25.45 \pm 0.4^{a}$ \\
\hline $16: 1$ & $3.24 \pm 0.5^{a}$ & $1.54 \pm 0.4^{b}$ & $1.30 \pm 0.3^{b}$ & $1.47 \pm 0.1^{b}$ \\
\hline 17:0 & $0.56 \pm 0.1$ & $1.02 \pm 0.2$ & $1.04 \pm 0.3$ & $1.10 \pm 0.2$ \\
\hline 18:0 & $15.21 \pm 0.7^{a}$ & $13.87 \pm 0.4^{\mathrm{ab}}$ & $12.45 \pm 0.6^{b}$ & $12.31 \pm 0.6^{b}$ \\
\hline $18: 1 n-9$ & $32.28 \pm 1.2^{\mathrm{a}}$ & $19.51 \pm 1.1^{\mathrm{ab}}$ & $15.54 \pm 0.5^{c}$ & $17.90 \pm 1.0^{b}$ \\
\hline $18: 2 n-6$ & $19.24 \pm 1.1^{b c}$ & $23.41 \pm 1.8^{\mathrm{a}}$ & $21.66 \pm 1.3^{\mathrm{ab}}$ & $15.92 \pm 1.0^{c}$ \\
\hline $18: 3 n-3$ & $0.42 \pm 0.1 b^{c}$ & $0.48 \pm 0.03^{b c}$ & $0.58 \pm 0.1^{\mathrm{ab}}$ & $0.66 \pm 0.1^{a}$ \\
\hline 20:4 n-6 & $3.81 \pm 0.2^{\mathrm{a}}$ & $2.93 \pm 0.6^{\mathrm{ab}}$ & $2.72 \pm 0.5 a^{b}$ & $1.94 \pm 0.1^{b}$ \\
\hline $20: 5 n-3$ & - & $2.32 \pm 0.1^{c}$ & $3.75 \pm 0.3^{b}$ & $5.18 \pm 0.7^{\mathrm{a}}$ \\
\hline $22: 6 n-3$ & - & $7.63 \pm 0.9^{b}$ & $11.07 \pm 0.7^{\mathrm{a}}$ & $13.03 \pm 0.6^{a}$ \\
\hline SFA & $40.06 \pm 1.0$ & $41.03 \pm 0.8$ & $41.99 \pm 1.1$ & $42.66 \pm 0.3$ \\
\hline UFA & $59.94 \pm 1.0$ & $58.97 \pm 0.8$ & $58.01 \pm 1.1$ & $57.34 \pm 0.3$ \\
\hline MUFA & $36.47 \pm 1.7^{\mathrm{a}}$ & $22.21 \pm 1 . b^{b}$ & $18.23 \pm 0.5^{\mathrm{b}}$ & $20.61 \pm 1.0^{b}$ \\
\hline PUFA $n-3$ & $0.42 \pm 0.1^{d}$ & $10.43 \pm 0.9^{c}$ & $15.39 \pm 0.8^{b}$ & $18.87 \pm 0.7^{\mathrm{a}}$ \\
\hline PUFA $n-6$ & $23.05 \pm 1.2^{\mathrm{a}}$ & $26.33 \pm 1.5^{\mathrm{a}}$ & $24.39 \pm 1.5^{\mathrm{a}}$ & $17.86 \pm 1.0^{\mathrm{b}}$ \\
\hline UFA: SFA & $1.51 \pm 0.1$ & $1.44 \pm 0.1$ & $1.39 \pm 0.1$ & $1.34 \pm 0.0$ \\
\hline PUFA: SFA & $0.59 \pm 0.03^{b}$ & $0.90 \pm 0.07^{\mathrm{a}}$ & $0.96 \pm 0.1^{a}$ & $0.86 \pm 0.03^{a}$ \\
\hline$n-6: n-3$ & $62.29 \pm 11.1^{\mathrm{a}}$ & $2.58 \pm 0.2^{b}$ & $1.61 \pm 0.2^{c}$ & $0.95 \pm 0.1^{c}$ \\
\hline
\end{tabular}

${ }^{\dagger}$ Dietary $n-3$ PUFA level of 0.5 (T1), 8.0 (T2), 11.5 (T3), 16.5\% (T4). $n=8$ birds/ treatment.

${ }^{\text {a-d }}$ Means with different superscripts within a row differ significantly $(P<0.05)$.

\section{Cytokine Production}

The IL-2 and IFN- $\gamma$ levels increased along with the $n-3$ PUFA enrichment pre and 2 days post-challenge from T2 group to T4 (Table 10). However, there was no difference in IFN- $\gamma$ level 2 days post-challenge and IL-2 and IFN- $\gamma 7$ days post-challenge. Surprisingly, both IL-2 and IFN- $\gamma$ were significantly higher in $\mathrm{T} 1$ than $\mathrm{T} 2$ before challenge.

\section{Discussion}

Fats and oils are usually provided for chicken as dietary energy source to enhance the productivity and fulfill the high energy demand of fast growing broilers. Among the different fats and oils, the high n- 6 PUFA sources are cheaper and easier available. Incorporation of these sources resulted in high concentration of the n-6 PUFA in the meat or egg product, and less EPA, (20:5 n-3), docosapentaenioc (DPA 22:5n-3) and DHA (22:6n-3) [21]. On the other hand, dietary n-3 PUFA enrichment and lowering $n-6: n-3$ PUFA ratio alters the fatty acid profile of meat toward long chain PUFA [22,23]. In agreement, current study results showed that the total $n$-3 PUFA, EPA and DHA of plasma and breast muscle significantly increased along with ascending n-3 PUFA inclusion from $\mathrm{T} 1$ to T4. There was a relatively high level of arachidonic acid (AA, 20:4n-6) to linoleic acid (LA, 18:2n-6) in
Table 6 Influence of dietary treatments on breast muscle fatty acid composition at $\mathbf{4 2}$ days of age in broiler chickens (\%).

\begin{tabular}{lcccc}
\hline & \multicolumn{4}{c}{ Treatments } \\
\cline { 2 - 5 } Fatty acids & T1 $^{\dagger}$ & T2 & T3 & T4 \\
\hline $14: 0$ & $0.66 \pm 0.04^{\mathrm{c}}$ & $0.79 \pm 0.03^{\mathrm{bc}}$ & $0.90 \pm 0.05^{\mathrm{ab}}$ & $1.07 \pm 0.06^{\mathrm{a}}$ \\
15:0 & $0.45 \pm 0.08$ & $0.42 \pm 0.04$ & $0.53 \pm 0.09$ & $0.56 \pm 0.06$ \\
$16: 0$ & $23.50 \pm 0.51$ & $21.82 \pm 0.46$ & $22.03 \pm 0.35$ & $21.64 \pm 1.48$ \\
16:1 & $2.81 \pm 0.45^{\mathrm{a}}$ & $1.29 \pm 0.14^{\mathrm{c}}$ & $1.63 \pm 0.26^{\mathrm{bc}}$ & $2.51 \pm 0.28^{\mathrm{ab}}$ \\
17:0 & $0.37 \pm 0.03$ & $0.60 \pm 0.10$ & $0.66 \pm 0.07$ & $0.71 \pm 0.10$ \\
18:0 & $10.01 \pm 0.51$ & $11.81 \pm 0.36$ & $11.71 \pm 0.68$ & $11.92 \pm 0.89$ \\
18:1 $n-9$ & $35.11 \pm 1.00^{\mathrm{a}}$ & $21.26 \pm 0.78^{\mathrm{b}}$ & $20.96 \pm 1.39^{\mathrm{b}}$ & $19.53 \pm 1.57^{\mathrm{b}}$ \\
18:2 $n-6$ & $16.47 \pm 0.41^{\mathrm{b}}$ & $20.57 \pm 0.90^{\mathrm{a}}$ & $16.24 \pm 1.06^{\mathrm{b}}$ & $14.77 \pm 1.49^{\mathrm{b}}$ \\
18:3 $n-3$ & $0.45 \pm 0.03$ & $0.42 \pm 0.03$ & $0.42 \pm 0.08$ & $0.59 \pm 0.08$ \\
20:4 $n-6$ & $5.67 \pm 0.70^{\mathrm{ab}}$ & $6.17 \pm 0.41^{\mathrm{a}}$ & $5.11 \pm 0.77^{\mathrm{ab}}$ & $3.95 \pm 0.61^{\mathrm{b}}$ \\
20:5 $n-3$ & - & $1.20 \pm 0.16^{\mathrm{b}}$ & $2.24 \pm 0.37^{\mathrm{a}}$ & $2.83 \pm 0.14^{\mathrm{a}}$ \\
22:6 $n-3$ & - & $8.26 \pm 0.74^{\mathrm{b}}$ & $13.13 \pm 0.82^{\mathrm{a}}$ & $14.84 \pm 1.18^{\mathrm{a}}$ \\
SFA & $35.99 \pm 0.52$ & $37.04 \pm 0.90$ & $37.27 \pm 1.01$ & $37.32 \pm 1.10$ \\
UFA & $64.01 \pm 0.52$ & $62.96 \pm 0.90$ & $62.73 \pm 1.01$ & $62.68 \pm 1.10$ \\
MUFA & $39.80 \pm 1.23^{\mathrm{a}}$ & $24.91 \pm 0.73^{\mathrm{b}}$ & $24.66 \pm 1.51^{\mathrm{b}}$ & $24.04 \pm 1.39^{\mathrm{b}}$ \\
PUFA $n-3$ & $0.45 \pm 0.03^{\mathrm{c}}$ & $9.88 \pm 0.82^{\mathrm{b}}$ & $15.79 \pm 0.96^{\mathrm{a}}$ & $18.26 \pm 1.19^{\mathrm{a}}$ \\
PUFA $n-6$ & $23.76 \pm 0.96^{\mathrm{b}}$ & $28.17 \pm 0.81^{\mathrm{a}}$ & $22.28 \pm 0.86^{\mathrm{b}}$ & $20.38 \pm 1.67^{\mathrm{b}}$ \\
UFA: SFA & $1.78 \pm 0.04$ & $1.71 \pm 0.07$ & $1.69 \pm 0.08$ & $1.69 \pm 0.08$ \\
PUFA: SFA & $0.67 \pm 0.02^{\mathrm{b}}$ & $1.03 \pm 0.05^{\mathrm{a}}$ & $1.02 \pm 0.03^{\mathrm{a}}$ & $1.05 \pm 0.09^{\mathrm{a}}$ \\
n-6: $\boldsymbol{n}-3$ & $54.29 \pm 4.79^{\mathrm{a}}$ & $2.96 \pm 0.29^{\mathrm{b}}$ & $1.45 \pm 0.15^{\mathrm{c}}$ & $1.14 \pm 0.12^{\mathrm{c}}$ \\
\hline
\end{tabular}

${ }^{\dagger}$ Dietary $n-3$ PUFA level of 0.5 (T1), 8.0 (T2), 11.5 (T3), 16.5\% (T4). $n=8$ birds/ treatment.

a-d Means with different superscripts within a row differ significantly $(P<$ 0.05).

plasma of T1 on day 28 and 42. This phenomenon can be explained by the absence of linolenic acid (LNA, 18:3 $n-3)$ in the diet of this group, while the other groups have LNA of $0.5,0.6$ and $0.6 \%$ (Table 2). Simopoulos [16] indicated that there is a competition between LA and LNA for conversion to the long-chain PUFA because they share the same enzymes and LNA is the preferred substrate. Moreover, there was no detectable DHA in plasma of $\mathrm{T} 1$ as their representative diet was also free of EPA and DHA and their precursor LNA.

Dietary n-3 PUFA enrichment also increased body weight and improved FCR as measured in T2 and T3 at 42 days of age. This may be due to the superior digestibility of unsaturated fatty acid compared to saturated type [24-27]. Newman [21] showed the modulatory effects of dietary $n-3$ and $n-6$ PUFA FCR in avian metabolism through the modulation of lipid deposition and oxidation. However, the enhancement was not observed in highest n3 PUFA (T4) group, leading to the postulation that effect of n-3 PUFA enrichment is a dose-dependent response. Hulan [28] reported that isoenergetic and isonitrogenous diets enriched with redfish meal and redfish oil led to lower body weights than the control diet. They attributed this result to lower palatability and higher calcium levels, 
Table 7 Effect of $n-3$ PUFA enrichment on performance and mortality of IBD challenged broiler chickens.

\begin{tabular}{|c|c|c|c|c|c|c|c|}
\hline \multirow[b]{2}{*}{ Treatments } & \multicolumn{3}{|c|}{ 1-21 days } & \multicolumn{3}{|c|}{ 1-42 days } & \multirow[b]{2}{*}{ Mortality (\%) } \\
\hline & Body weight (g) & Feed intake (g/bird) & FCR & Body weight (g) & Feed intake (g/bird) & FCR & \\
\hline $\mathrm{T}^{+}$ & $798 \pm 10$ & $1397 \pm 25$ & $1.75 \pm 0.02$ & $2215 \pm 30^{\mathrm{ab}}$ & $4740 \pm 87$ & $2.05 \pm 0.03^{\mathrm{a}}$ & $7 \pm 2$ \\
\hline $\mathrm{T} 2$ & $788 \pm 11$ & $1366 \pm 33$ & $1.75 \pm 0.03$ & $2276 \pm 28^{\mathrm{a}}$ & $4568 \pm 74$ & $1.94 \pm 0.03^{b}$ & $7 \pm 2$ \\
\hline T3 & $801 \pm 10$ & $1335 \pm 9$ & $1.72 \pm 0.03$ & $2251 \pm 28^{\mathrm{a}}$ & $4689 \pm 66$ & $1.97 \pm 0.03^{\mathrm{ab}}$ & $7 \pm 2$ \\
\hline T4 & $783 \pm 9$ & $1403 \pm 16$ & $1.78 \pm 0.03$ & $2147 \pm 29^{b}$ & $4570 \pm 40$ & $2.05 \pm 0.03^{\mathrm{a}}$ & $8 \pm 2$ \\
\hline
\end{tabular}

${ }^{\dagger}$ Dietary $n$-3 PUFA level of 0.5 (T1), 8.0 (T2), 11.5 (T3), 16.5\% (T4). $n=75$ birds/treatment.

a-b Means within a column with different letters differ significantly $(P<0.05)$.

although no palatability problem as a result of n-3 PUFA supplementation in the diet was found in the present study. Evidently, significant differences due to dietary treatment are absent from the feed intake throughout the experimental period. In any case, in accordance Korver [29] demonstrated that low levels of dietary fish oil were more efficient than high levels in improving broiler growth rate and FCR, even when the birds were undergoing an inflammatory response.

Immune tissue development can in some cases reflect immune system response and functionality. In the current study, there was no affect of dietary treatment on the bursa of Fabricius weight and lesion score, but spleen weight increased as the level of n-3 PUFA in diet increased 7 days post-challenge. Some other studies reported that feeding PUFA to chickens [30] and mice [31] results in increased spleen weights. In the study of Wang [30], the author used single-comb White Leghorn layers fed sunflower oil, animal oil, linseed oil, or fish oil at 5\% (wt/wt). The results demonstrated that chicks fed the 3 PUFA-rich diets had significantly higher weights of the thymus, spleen, and bursa compared with those of chicks fed the diet with animal oil. In our study, the spleen enlargement due to dietary n-3 PUFA enrichment accompanied with the same trends of IBD and ND antibody responses, boosting immune system and enhance spleen task. Increasing of the IBD and ND titer can be explained by the fact that IL-2 is able to facilitate production of immunoglobulins made by $\beta$ cells. Anti-sheep red blood cell antibody responses of rats fed $17 \mathrm{~g}$ fish oil were significantly higher than corn oil fed rats [32]. The $\beta$ cell population is not affected by dietary fat in non-infected mice, but the fish oil enrichment results in the highest percentage of $\beta$ cells in infected mice [33]. Furthermore, fortifying the diet with n-3 PUFA from fish oil (5\%) significantly increased serum IgG concentration and IgM+ B cells in chicken [30]. Immunoglobulin $\mathrm{M}$ as the major antibody in the primary immune response reduces in circulating system during the acute lytic phase of the IBD virus $[8,10,11]$. The present study provides the evidences for immuno-stimulating properties of dietary n-3 PUFA in IBD infected chicken through antibody body response improvement and probably IgM-bearing B lymphocyte proliferation.

One of the interesting results of the current study is the ascending elevation of IL- 2 and IFN- $\gamma$ concentrations along with the $n-3$ PUFA enrichment from T2 to T4. Cytokine production plays an important role in mounting a complete and full immune response of both the innate and specific systems. These cytokines are produced by $\mathrm{T}$ helper lymphocytes (Th1) and activate macrophages, NK cells, and cytotoxic $\mathrm{T}$ lymphocytes and are the principal effectors of cell-mediated immunity. Interactions with bacteria, viruses, and fungi tend to induce Th1 activity. Because Th1 cytokines activate monocytes and macrophages, these cytokines may be regarded as pro-inflammatory. Interlukin-2 can enhance interferon production [34,35]. Interferon- $\gamma$ is a cytokine that is critical for innate and adaptive immunity against viral and intracellular bacterial infections. A close relationship exists between cytokine synthesis and $n-3$ fatty acids. It is possible that eicosanoid production derived from $n$-3 PUFA might stimulate the production of IL-2 and IFN- $\gamma[36,37]$. At present, the mechanisms by which dietary $n-3$ PUFA modulate cytokine production is not clarified. However, the possible mechanism might be the

Table 8 Effect of $n-3$ PUFA enrichment on relative lymphoid organ weight in IBD challenged broiler chickens.

\begin{tabular}{lcccccc}
\hline Treatment & Spleen & & & \multicolumn{2}{c}{ Bursa of Fabricius } \\
\cline { 2 - 7 } & Pre-challenge & $\begin{array}{c}7 \text { days } \\
\text { post-challenge }\end{array}$ & $\begin{array}{c}14 \text { days } \\
\text { post-challenge }\end{array}$ & Pre-challenge & $\begin{array}{c}7 \text { days } \\
\text { post-challenge }\end{array}$ & $\begin{array}{c}14 \text { days } \\
\text { post-challenge }\end{array}$ \\
\hline $\mathrm{T} 1^{\dagger}$ & $0.10 \pm 0.004$ & $0.06 \pm 0.003^{\mathrm{b}}$ & $0.08 \pm 0.008$ & $0.18 \pm 0.005$ & $0.11 \pm 0.009$ & $0.04 \pm 0.004$ \\
$\mathrm{~T} 2$ & $0.10 \pm 0.010$ & $0.09 \pm 0.009^{\mathrm{ab}}$ & $0.08 \pm 0.010$ & $0.23 \pm 0.007$ & $0.10 \pm 0.010$ & $0.05 \pm 0.005$ \\
$\mathrm{~T} 3$ & $0.11 \pm 0.008$ & $0.09 \pm 0.008^{\mathrm{ab}}$ & $0.09 \pm 0.011$ & $0.22 \pm 0.02$ & $0.11 \pm 0.010$ & $0.05 \pm 0.002$ \\
$\mathrm{~T} 4$ & $0.09 \pm 0.009$ & $0.12 \pm 0.008^{\mathrm{a}}$ & $0.09 \pm 0.010$ & $0.22 \pm 0.02$ & $0.10 \pm 0.009$ & $0.04 \pm 0.004$ \\
\hline
\end{tabular}

${ }^{\dagger}$ Dietary $n-3$ PUFA level of 0.5 (T1), 8.0 (T2), 11.5 (T3), 16.5\% (T4). $n=8$ birds/treatment.

a-b Means within a column with different letters differ significantly $(P<0.05)$. 
Table 9 Effect of $n-3$ PUFA enrichment on histopathological changes (lesion score) of bursa in IBD challenged broiler chickens.

\begin{tabular}{lccc}
\hline Treatment & Pre-challenge & $\begin{array}{c}\text { 7 days } \\
\text { post-challenge }\end{array}$ & $\begin{array}{c}\text { 14 days } \\
\text { post-challenge }\end{array}$ \\
\hline T1 $^{\dagger}$ & $0.5 \pm 0.2$ & $2.0 \pm 0.4$ & $3.8 \pm 0.2$ \\
T2 & $0.3 \pm 0.2$ & $3.2 \pm 0.5$ & $3.0 \pm 0.7$ \\
T3 & $0.3 \pm 0.2$ & $3.0 \pm 0.3$ & $3.7 \pm 0.2$ \\
T4 & $0.6 \pm 0.2$ & $2.2 \pm 0.3$ & $3.5 \pm 0.3$ \\
\hline
\end{tabular}

${ }^{\dagger}$ Dietary $n$-3 PUFA level of 0.5 (T1), 8.0 (T2), 11.5 (T3), 16.5\% (T4). $\mathrm{n}=8$ birds/treatment.

decreased production of metabolites of $n-6$ PUFA, such as $\mathrm{PGE}_{2}$ and changes in phospholipids composition of immune cell membranes. Some studies suggested the PGE2 which is derived from arachidonic acid and $n-6$ PUFA as the possible candidate for inhibition of $\mathrm{T}$ cell proliferation, Th1 cell, IL-2 and IFN- $\gamma$ production [38-40]. The $\mathrm{PGE}_{2}$ primes human naive $\mathrm{T}$ cells in a dose-dependent fashion for production of high levels of IL-4, IL-10, and IL13 and very low levels of IL-2 and IFN- $\gamma$ [41]. Furthermore, some researchers noted that high levels of dietary fish oil apparently have different immunomodulatory effects than lower levels [42]. It is reported that $n-3$ PUFA decreases production of $\mathrm{PGE}_{2}$ [43] due to a competition between $n-3$ PUFA and $n-6$ PUFA for incorporation into the cell membrane phospholipids. This finding is in contrast with the result of dietary fish oil supplementation in human $[4,36]$ and rat [44]. However, these findings are consistent with the effects of dietary supplementation in non-human primates [45] in human [43,46] and mice [47]. A possible explanation for the contrast in results between the present study and other reported studies may referred to the intake levels EPA and DHA, source and type of oil and the concentration of dietary fat. There is another highlight in the current study results on the IL- 2 and IFN- $\gamma$ concentration where high level of these cytokines observed in T1 chickens that received the lowest amount of n-3 PUFA. There is no clear explanation for the phenomenon, but it may speculated that this observation is contributed to the doseresponse characteristic of the immune functions to $n-3$ PUFA levels $[41,42]$ or low level of linoleic acid in T1 compare to the other groups. Linoleic acid reported to inhibit the proliferation of rodent and human lymphocytes and decrease the production of IL-2 by mitogenstimulated rat and human lymphocytes $[5,48,49]$, suggesting that it is potentially immunosuppressive.

\section{Conclusions}

In conclusion, dietary n-3 PUFA enrichment may improve the immune response and IBD resistance, but the optimum performance does not coincide with the optimum immune response. It seems that dietary n-3 PUFA modulates the broiler chicken performance and immune response to IBD challenge in a dose-dependent manner. Thus, a moderate level of dietary n-3 PUFA enrichment may help to put together the efficiency of performance and relative immune response enhancement in broiler chickens.

\section{Methods}

\section{Birds and Housing Environment}

A total of three hundred day-old male broiler chicks (Cobb 500) were obtained from a local hatchery. The chicks were wing-banded, individually weighed, and housed. The birds were raised on conventional deep litter system in an open sided house with cyclic temperatures (minimum, $24^{\circ} \mathrm{C}$; maximum, $34^{\circ} \mathrm{C}$ ). The relative humidity was between 60 to $80 \%$. The area of each pen was $2 \mathrm{~m}^{2}$. Feed and water were provided ad libitium and lighting was continuous. The chicks were vaccinated against Newcastle disease (Animal Health, Fort Dodge, Iowa, USA) on day 7 (intraocular) and on day 21(intranasal).

\section{Experimental Design}

Experimental procedure was approved by the ACUC Animal Care and Use Committee of the University of Putra Malaysia. Commencing from day one, five replicate pens of 15 chicks each were assigned to one of the four dietary treatments, giving a total of 20 pens. There were four dietary $n-3$ PUFA ascending levels as the treatment groups (T1: 0.5; T2: 8.0; T3: 11.5; T4: 16.5) achieved using a combinations of tuna oil, sunflower oil and palm oil in feed formulation (Table 1). All diets were isocaloric and isonitrogenous. The diets (mash form) were formulated to meet or exceed requirements by the NRC [50] for broiler chickens. The diets were prepared weekly and kept at $4{ }^{\circ} \mathrm{C}$ to prevent rancidity and oxidation. No antimicrobial, anticoccidial drugs or feed enzymes were included in the diets.

\section{Performance Parameters}

All chickens were individually weighed weekly. Feed intake per group was recorded weekly and feed conversion ratios (FCR) were calculated. Mortality was recorded daily in each subgroup.

\section{Challenge Protocol}

On day 28 of age, all birds were challenged by an oral route with a commercial live IBD vaccine (V877 strain, Malaysian Vaccines and Pharmaceuticals Sdn. Bhd). The strain was characterized as an intermediate classical strain. Each bird was inoculated with a dose of $10^{4.0} \mathrm{EID}_{50}$ IBD virus into the lumen of the crop by oral gavage [51].

\section{Lymphoid Organ Weight and Histopathological Examination}

Prior to IBD challenge (d 28), 7 and $14 \mathrm{~d}$ post-challenge, eight birds from each group were chosen randomly and 

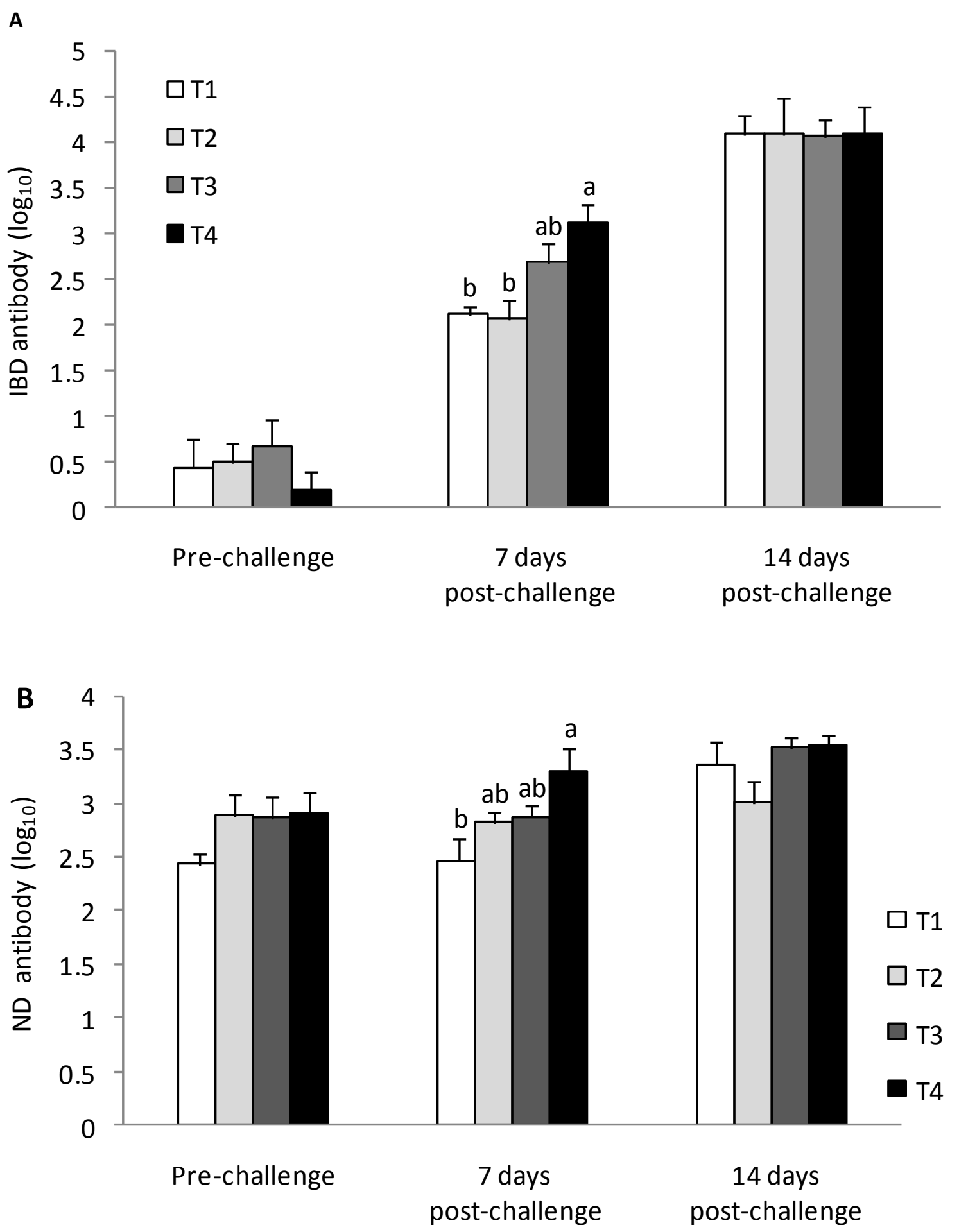

Figure 1 Effects of $n-3$ PUFA enrichment on serum IBD (A) and ND (B) antibody titers $\left(\log _{10}\right)$ in IBD challenged broiler chickens. Dietary n-3 PUFA levels were as follows: 0.5 (T1), 8.0 (T2), 11.5 (T3), 16.5\% (T4). Measurements were on 28 days of age (Pre-challenge) and 7 and 14 days after the IBD challenge. ${ }^{\mathrm{a}-\mathrm{b}}$ Means with no common letter within sampling time subgroup differ $P<0.05 . \mathrm{n}=10$ birds/treatment.

killed by cervical dislocation, the bursas of Fabricius and spleen were removed and their weight recorded and presented as relative to body weight [52]. The bursas of
Fabricius were then fixed in $10 \%$ buffered formalin, processed for histology, and lesions were scored from 0 to 5 according to the modified criteria described by 
Table 10 Effects of $n-3$ PUFA enrichment on serum IL-2 and INF- $\gamma$ concentrations in IBD challenged broiler chickens.

\begin{tabular}{|c|c|c|c|c|c|c|}
\hline \multirow[b]{2}{*}{ Treatment } & \multicolumn{3}{|c|}{$\begin{array}{c}\mathrm{IL}-2 \\
(\mathrm{ng} / \mathrm{ml})\end{array}$} & \multicolumn{3}{|c|}{$\begin{array}{c}\text { INF- } \gamma \\
\text { (ng/ml) }\end{array}$} \\
\hline & Pre-challenge & $\begin{array}{c}2 \text { days } \\
\text { post-challenge }\end{array}$ & $\begin{array}{c}7 \text { days } \\
\text { post-challenge }\end{array}$ & Pre-challenge & $\begin{array}{c}2 \text { days } \\
\text { post-challenge }\end{array}$ & $\begin{array}{c}7 \text { days } \\
\text { post-challenge }\end{array}$ \\
\hline $\mathrm{T}^{\dagger}$ & $7.9 \pm 1.0^{\mathrm{a}}$ & $7.2 \pm 0.7^{b}$ & $5.8 \pm 1.7$ & $5.7 \pm 1.0^{\mathrm{a}}$ & $7.9 \pm 1.3$ & $5.3 \pm 1.9$ \\
\hline $\mathrm{T} 2$ & $2.9 \pm 0.7^{b}$ & $5.1 \pm 1.5^{b}$ & $6.8 \pm 1.0$ & $2.1 \pm 0.7^{b}$ & $6.9 \pm 0.9$ & $5.7 \pm 1.1$ \\
\hline T3 & $6.5 \pm 1.2^{\mathrm{a}}$ & $6.3 \pm 0.6^{b}$ & $4.5 \pm 1.3$ & $3.6 \pm 0.7^{\mathrm{ab}}$ & $7.4 \pm 2.0$ & $4.4 \pm 1.6$ \\
\hline T4 & $8.4 \pm 0.9^{a}$ & $10.6 \pm 1.0^{\mathrm{a}}$ & $5.3 \pm 0.6$ & $6.2 \pm 0.9^{a}$ & $7.7 \pm 1.9$ & $5.8 \pm 1.9$ \\
\hline
\end{tabular}

${ }^{\dagger}$ Dietary $n$-3 PUFA level of 0.5 (T1), 8.0 (T2), 11.5 (T3), 16.5\% (T4). $n=5$ birds/treatment.

a-b Means within a column with different letters differ significantly $(P<0.05)$.

Muskett [53]. The breast muscle samples also were collected and frozen quickly in liquid nitrogen, and stored at $-70^{\circ} \mathrm{C}$ until further analysis for fatty acids profile.

\section{Fatty acid Extraction and Identification}

The total fatty acids were extracted from diets, oils and breast muscle samples using chloroform: methanol 2:1 (v/v) based on the Folch [54] modified by Rajion [55] with an antioxidant to prevent the oxidation during sample preparation. The experimental diets and plasma were homogenized in $40 \mathrm{ml}$ chloroform: methanol (2:1 v/v) using an Ultra-Turrax T5 FU homogenizer (IKA Analysentechnik GmBH, Germany). Transmethylation of the extracted fat to fatty acid methyl esters (FAME) were carried out using $\mathrm{KOH}$ in methanol and $14 \%$ methanolic boron triflouride $\left(\mathrm{BF}_{3}\right)$ (Sigma Chemical Co. St. Louis, Missouri, USA) according to methods in AOAC [56]. The methyl esters were quantified by gas chromatography (Agilent $7890 \mathrm{~N}$ ) using a $30 \mathrm{~m} \times 0.25$ mm ID $(0.20 \mu \mathrm{m}$ film thickness) Supelco SP-2330 capillary column (Supelco, Inc., Bellefonte, PA, USA). One microliter of FAME was injected by an auto sampler into the chromatograph, equipped with a split/splitless injector and a flame ionization detector (FID). The injector temperature was programmed at $250^{\circ} \mathrm{C}$ and the detector temperature was $300^{\circ} \mathrm{C}$. The column temperature program initiated runs at $100^{\circ} \mathrm{C}$, for $2 \mathrm{~min}$, warmed to $170^{\circ} \mathrm{C}$ at $10^{\circ} \mathrm{C} / \mathrm{min}$, held for $2 \mathrm{~min}$, warmed to $220^{\circ} \mathrm{C}$ at $7.5^{\circ} \mathrm{C} / \mathrm{min}$, and then held for $20 \mathrm{~min}$ to facilitate optimal separation. All results of fatty acid were presented as the percentage of total fatty acids. All peaks were quantified using fatty acid standards (Supelco 18919, fatty acid methyl ester mixture, USA).

\section{Serology}

Prior to IBD challenge ( $\mathrm{d} 28$ ), 7 and $14 \mathrm{~d}$ post-challenge, ten birds from each group were chosen at random, and blood samples were collected from the brachial vein. Serum was separated by centrifugation (3000 g, 15 minutes) and antibody titre against ND and IBD were measured using commercially available ELISA kits (Bio-check B.V., Gouda, Holland) according to manufacturer's instructions. The absorbance of controls and samples were read at $405 \mathrm{~nm}$ using an ELISA reader (Bio-Tek Instruments Inc. ELX 800; Winooski, VT).

\section{Cytokine Measurement}

The serum levels of IL- 2 and IFN- $\gamma$ were determined using a chicken specific ELISA kits (Cusabio Biotech, USA). The procedure was following the procedure recommended by the manufacturer.

\section{Statistical Analysis}

A completely randomized design (CRD) with five replicates was employed for this study. Statistical analyses were conducted using one-way ANOVA general linear models. Means were separated by Duncan's multiple range tests. Antibody titers of IBD and ND were logarithmically transformed prior to analysis to achieve homogeneity of variance and were expressed as $\log _{10}$. The IL-2 and IFN- $\gamma$ data were normalized using square root transformation prior to analysis. Mortality data were subjected to chi-square analysis. The results were expressed as mean \pm SEM. Statistical significance was considered at $\mathrm{P}<0.05$.

\section{List of Abbreviations}

IBD: infectious bursal disease; ND: Newcastle disease; IL: interleukin; IFN: Interferon; ELIZA: Enzyme-linked immunosorbent assay; SRBC: sheep red blood cell; PGE2: prostaglandin E2; PUFA: polyunsaturated fatty acid.

\section{Acknowledgements}

The authors would like to express their gratitude to Mr. Mazlan Hamzah and Ponnusamy Muniandy the staff of Animal Science Department of Agriculture Faculty, University of Putra Malaysia for their technical assistance during the experimental period.

\section{Author details}

${ }^{1}$ Department of Animal Science, Universiti Putra Malaysia,43400 UPM Serdang, Selangor, Malaysia. ${ }^{2}$ Department of Veterinary Preclinical Sciences, Universiti Putra Malaysia, 43400 UPM Serdang, Selangor, Malaysia.

${ }^{3}$ Department of Veterinary Pathology and Microbiology, Universiti Putra Malaysia, 43400 UPM Serdang, Selangor, Malaysia. ${ }^{4}$ Department of animal science, Faculty of Agriculture, Ferdowsi University of Mashhad, Mashhad, Iran.

\section{Authors' contributions}

EM, AFS and ME conceived and designed the study, participated in data collection and analyses and drafted the manuscript; AK, TCL, FH, MHB 
participated in the design of the study and drafted the manuscript. YMG participated in the data analyses and fatty acid analysis; TZ helped for the interpretation of the histopathological examination. All authors read and approved the final manuscript.

\section{Competing interests}

The authors declare that they have no competing interests.

Received: 27 November 2011 Accepted: 25 January 2012 Published: 25 January 2012

\section{References}

1. Cinader B, Clandinin MT, Hosokawa T, Robblee NM: Dietary fat alters the fatty acid composition of lymphocyte membranes and the rate at which suppressor capacity is lost. Immunol Lett 1983, 6:331-337.

2. Huang SC, Fritsche KL: Alteration in mouse splenic phospholipid fatty acid composition and lymphoid cell populations by dietary fat. Lipids 1992, 27:25-32

3. Wall R, Ross RP, Fitzgerald GF, Stanton C: Fatty acids from fish: the anti inflammatory potential of long chain omega 3 fatty acids. Nutr rev 2010, 68:280-289.

4. Meydani SN, Endres S, Woods MM: Oral n-3 fatty acid supplementation suppresses cytokine production and lymphocyte proliferation: comparison between young and older women. J Nutr 1991, 121:547-55.

5. Calder PC: $n-3$ Polyunsaturated fatty acids, inflammation, and inflammatory diseases. Am J Clin Nutr 2006, 83:1505S-1519S.

6. Kibenge FSB, Dhillon AS, Russell RG: Biochemistry and immunology of infectious bursal disease virus. J Gen Virol 1988, 69:1757-1775.

7. Liu H, Zhang M, Han H, Yuan J, Li Z: Comparison of the expression of cytokine genes in the bursal tissues of the chickens following challenge with infectious bursal disease viruses of varying virulence. J Virol 2010, 7:360-364

8. Sharma JM, Kim IJ, Rautenschlein S, Yeh HY: Infectious bursal disease virus of chickens: pathogenesis and immunosuppression. Dev Comp Immunol 2000, 24:223-235.

9. Ivanyi J, Morris R: Immunodeficiency in the chicken. Part IV: An immunological study of infectious bursal disease. Clin Exp Immun 1976, 23:154-165.

10. Rodenberger JK, Sharma JM, Balzer S, Nordgren R, Naqi S: Flow cytometric analysis of B-cell and T-cell subpopulations in specific pathogen-free chickens infected with infectious bursal disease virus. Avian Dis 1994, 38:16-21.

11. Tanimura N, Sharma JM: Appearance of T cells in the bursa of Fabricius and cecal tonsils during the acute phase of infectious bursal disease virus infection in chickens. Avian Dis 1997, 41:638-645.

12. Sugano M, Koga T, Yamada K: Lipids and immunology. Asia Pacific J Clin Nutr 2000, 9:146-152

13. Prickett JD, Robinson DR, Bloch KJ: Enhanced production of IgE and IgG antibodies associated with a diet enriched in eicosapentaenoic acid. Immunology 1982, 46:819-826.

14. Xi S, Cohen D, Chen LH: Effects of fish oil on cytokines and immune functions of mice with murine AIDS. J Lipid Res 1998, 39:1677-1687.

15. Beli E, Li M, Cuff C, Pestka JJ: Docosahexaenoic acid-enriched fish oil consumption modulates immunoglobulin responses to and clearance of enteric retrovirus infection in mice. J Nutr 2008, 138:813-819.

16. Simopoulos AP: Omega-3 fatty acids in health and disease and in growth and development. Am J Clin Nutr 1991, 54:438-63.

17. Anderson $M$, Fritsche $K L$ : (n-3) Fatty acids and infectious disease resistance. J Nutr 2002, 132:3566-3576.

18. Rockett BD, Salameh M, Carraway K, Morrison K, Shaikh SR: n-3 PUFA improves fatty acid composition, prevents palmitate-induced apoptosis, and differentially modifies $B$ cell cytokine secretion in vitro and ex vivo. J Lipid Res 2010, 51:1284-1297.

19. Ackman RG, Ratnayake WMN, Macpherson EJ: EPA and DHA contents of encapsulated fish oil products. JAOCS 1982, 66:1162-1164.

20. Howe PRC, Downing JA, Grenyer BFS, Grigonis-Deane EM, Bryden WL: Tuna fishmeal as a source of DHA for n-3 PUFA enrichment of pork, chicken, and eggs. Lipids 2002, 37:1067-1076.

21. Newman RE, Bryden WL, Fleck E, Ashes JR, Buttemer WA, Storlien LH, Downing JA: Dietary $n-3$ and $n-6$ fatty acids alter avian metabolism: metabolism and abdominal fat deposition. Br J Nutr 2007, 88:11-18.
22. Phetteplace HW, Watkins BA: Effects of various $n-3$ lipid sources on fatty acid compositions in chicken tissues. Poult Sci 1992, 71:1515-1519.

23. Bou R, Guardiola F, Tres A, Barroeta AC, Codony R: Effect of dietary fish oil, alpha-tocopherl acetate, and zinc supplementation on the composition and consumer acceptability of chicken meat. Poult Sci 2004, 83:282-292.

24. Ketels $E$, DeGroote $G$ : Effect of ratio of unsaturated to saturated fatty acids of the dietary lipid fraction on utilization and metabolizable energy of added fats in young chicks. Poult Sci 1989, 68:1506-1512.

25. Dvorin A, Zoref Z, Mokady S, Nitsan Z: Nutritional aspects of hydrogenated and regular soybean oil added to diets of broiler chickens. Poult Sci 1998, 77:820-825.

26. Pinchasov $Y$, Nir I: Effect of dietary polyunsaturated acid concentration on performance, fat deposition and carcass fatty acid composition in broiler chickens. Poult Sci 1992, 71:1504-1512.

27. Zollitsch W, Knaus W, Aichinger F, Lettner F: Effects of different dietary fat sources on performance and carcass characteristics of broilers. Anim Feed Sci Technol 1997, 66:63-73.

28. Hulan HW, Ackman RG, Ratnayake WMN, Proudfoot FG: Omega-3 fatty acid levels and performance of broilers chickens fed redfish meal or redfish oil. Can J Anim Sci 1988, 68:533-547.

29. Kover DR, Roura E, Klasing KC: Effect of dietary energy level and oil source on broiler performance and response to an inflammatory challenge. Poult Sci 1998, 77:1217-1227.

30. Wang YW, Field C, Sim JS: Dietary polyunsaturated fatty acids alter lymphocyte subset proportion and proliferation, serum immunoglobulin $\mathrm{G}$ concentration, and immune tissue development in chicks. Poult SCi 2000, 79:1741-1748.

31. Ellis NK, Young MR, Nikcevich DA, Newby M, Plioplys R, Wepsic HT: Stimulation of prostaglandin-dependent macrophage suppressor cells by the subcutaneous injection of polyunsaturated fatty acids. Cell Immunol 1986, 102:251-260.

32. Fritsche $\mathrm{KL}$, Cassity NA: Dietary ( $n-3)$ fatty acids reduce antibody dependent cell cytotoxicity and alter eicosanoid release by chicken immune cells. Poult Sci 1992, 71:1646-1657.

33. Huang SC, Misfeldt ML, Fritsche KL: Dietary fat influences antigen expression and immune cell populations in the murine peritoneum and spleen. Nutrition 1992, 122:1219-1231

34. Son $\mathrm{YI}$, Dallal RM, Mailliard RB, Egawa S, Jonak ZL, Lotze MT: Interleukin-18 (IL-18) synergizes with IL-2 to enhance cytotoxicity, interferonproduction, and expansion of natural killer cells. Cancer res 2001, 61:884-888.

35. Coquet JM, Kyparissoudis K, Pellicci DG, Besra G, Berzins SP, Smyth MJ, Godfrey DI: IL-21 is produced by NKT cells and modulates NKT cell activation and cytokine production. J Immunol 2007, 178:2827-2835.

36. Endres S: $n-3$ polyunsaturated fatty acids and human cytokine synthesis. Lipids 1996, 31:239-242.

37. Miles $E_{,}$Calder $P C$ : Modulation of immune function by dietary fatty acids. Proc Nutr Soc 1998, 57:277-292.

38. Goodwin JS, Webb DR: Regulation of the immune response by prostaglandins. J Clin Immunol 1983, 3:295-315.

39. Fedyk ER, Brown DM, Phipps RP: PGE2 regulation of B lymphocytes and $T$ helper 1 and T helper 2 cells: induction of inflammatory versus allergic responses. Adv Exp Med Biol 1997, 407:237-42

40. Betz M, Fox BS: Prostaglandin E2 inhibits production of Th1 lymphokines but not of Th2 lymphokines. J Immunol 1991, 146:108-113.

41. Demeure CE, Yang L. Desjardins P, Raynauld C, Delespesse G: Prostaglandin E2 primes naïve $T$ cells for the production of anti-inflammatory cytokines. Eur J Immunol 1997, 27:3526-3531.

42. Korver DR, Klasing KC: Dietary fish oil alters specific and inflammatory immune responses in chicks. Nutrition 1997, 127:2039-2046.

43. Trebble T, Arden NK, Stroud MA, Wootton SA, Burdge GC, Miles EA, Ballinger $A B$, Thompson RL, Calder PC: Inhibition of tumour necrosis factor-alpha and interleukin 6 production by mononuclear cells following dietary fish-oil supplementation in healthy men and response to antioxidant co-supplementation. Br J Nutr 2003, 90:405-41.

44. Ogita K, Suita S, Taguchi T, Yamanouchi T, Nakamura M, Taguchi S, Nishimoto $Y$, Uesugi T: Effects of omega-3 fatty acids in rat allogeneic small intestinal transplantation. Pediatr Surg Int 2003, 19:157-161.

45. Wu D, Meydani SN, Meydani M, Hayek MG, Huth P, Nicolosi RJ: Immunologic effects of marine- and plant-derived $\mathrm{n} 3$ polyunsaturated fatty acids in nonhuman primates. Am J Clin Nutr 1996, 163:273-80. 
46. Kemen M, Senkal M, Homann HH, Mumme A, Dauphin AK, Baier J, Neumann $\mathrm{H}$, Zumtobel V: Early postoperative enterai nutrition with arginine-omega-3 fatty acids and ribonucleic acid-supplemented diet versus placebo in cancer patients: an immunologie evaluation of impact. Crit Care Med 1995, 23:652-659.

47. Blok WL, Katan MB, Vandermeer JW: Modulation of inflammation and cytokine production by dietary (n-3) fatty acids. J Nutr 1996, 126:1515-33.

48. Jolly CA, Jiang YH, Chapkin RS, Mcmurray DN: Dietary (n-3) polyunsaturated fatty acids suppress murine lymphoproliferation interleukin-2 secretion, and the formation of diacylglycerol and ceramide. Nutrition 1997, 127:37-43.

49. Calder PC, Bevan SJ, Newsholme EA: The inhibition of T-lymphocyte proliferation by fatty acids is via an eicosanoid-independent mechanism. Immunology 1992, 75:108-115.

50. National research council: Nutrient requirements of poultry Washington DC: National Academy Press; 1994.

51. Liew PK, Zulkifli I, Hair-Bejo M, Omar AR, Israf DA: Effects of early age feed restriction and heat conditioning on heat shock protein 70 expression, resistance to infectious bursal disease, and growth in male broiler chickens subjected to heat stress. Poult Sci 2003, 82:1879-1885.

52. Giambrone JL, Closser J: Efficacy of live vaccines against serologic subtypes of infectious bursal disease virus. Avian Dis 1990, 34:7-1.

53. Muskett JC, Hopkins IG, Edwards KP, Thornton DH: Comparison of two infectious bursal disease vaccine strains: Efficacy and potential hazards in susceptible and maternally immune birds. Vet Rec 1979, 104:332-334.

54. Folch JM, Lees MP, Stanley GHS: A simple method for the isolation and purification of total lipids from animal tissues. Biol Chem 1957, 226:497-509.

55. McLean JG, Cahill RN: Essential fatty acids in the fetal and newborn lamb. Aust J Biol Sci 1985, 38:33-40

56. AOAC: Official methods of analysis Washington DC: Association of official analytical chemists; 2000

\section{doi:10.1186/1476-511X-11-15}

Cite this article as: Maroufyan et al:: Omega-3 polyunsaturated fatty acids enrichment alters performance and immune response in infectious bursal disease challenged broilers. Lipids in Health and Disease 2012 11:15.

\section{Submit your next manuscript to BioMed Central and take full advantage of:}

- Convenient online submission

- Thorough peer review

- No space constraints or color figure charges

- Immediate publication on acceptance

- Inclusion in PubMed, CAS, Scopus and Google Scholar

- Research which is freely available for redistribution 